\title{
İmplantasyon dışı tedavi yöntemleri (antibiyotik baskılama, artrodez, salvage işlemler)
}

\author{
Treatment methods other than implantation \\ (antibiotic suppression, arthrodesis, salvage prosedures) \\ Cengiz Şen, Gökhan Polat \\ İstanbul Üniversitesi İstanbul Tıp Fakültesi, Ortopedi ve Travmatoloji Anabilim Dalı, İstanbul
}

\begin{abstract}
Periprostetik eklem enfeksiyonları, günümüzde artroplasti ameliyatlarındaki artışa paralel olarak, daha sık görülür hale gelmiştir. Bu enfeksiyonların tedavisinde, irrigasyon-debridman, antibiyoterapi, tek basamaklı revizyon, iki basamaklı revizyon gibi birçok tedavi tanımlanmıştır. Buna rağmen başarısız olunan hastalarda; enfeksiyonun gelişim süreci, semptomların süresi, etken organizmanın virulansı, eklemin genel durumu (kemik kaybı ya da eklem üzerini örten yumuşak dokudaki yetersizlikler vb.), hastanın beklentisi, hastanın bağışıklık durumu ve komorbid faktörleri (böbrek yetmezliği, karaciğer yetmezliği immün yetmezlik, periferik arter hastalığı vb.) ve bunlara bağı olarak, hastaların tedavisinde implantasyon dışı tedavi yöntemleri (uzun süre antibiyotik baskılama, rezeksiyon artroplastisi, artrodez, ampütasyon) göz önünde bulundurulmalıdır. Bu tedavilerin başarısında, hasta seçiminin önemi akıldan çıkarılmamalıdır.
\end{abstract}

Anahtar sözcükler: uzun dönem antibiyotik baskılama; rezeksiyon artroplastisi; artrodez; interkalar protez; ampütasyon

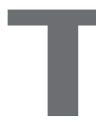
otal eklem artroplastisi, tüm Dünya'ya paralel olarak, ülkemizde de giderek artan miktarda uygulanmaktadır. ${ }^{[1,2]}$ Bununla birlikte, komplikasyon gelişen ve başarısız sonuç alınan hastaların sayısı da giderek artmaktadır. ${ }^{[2]}$ Total eklem replasmanı sonrası başarısızlık nedenlerinin başında, periprostetik eklem enfeksiyonları (PEE) gelmektedir ve bu durum, hastalar için belirgin bir psikolojik ve fiziksel morbidite yaratmaktadır. ${ }^{[3]}$

Periprostetik enfeksiyonlar klinikte karşımıza, enfeksiyon kliniğinin gelişim zamanına göre; akut postoperatif enfeksiyon, derin geç enfeksiyon ve geç hematojenik enfeksiyon olmak üzere üç tipte çıkmaktadır. ${ }^{[4]}$ Enfeksiyon kliniğinin ortaya çıkışı; etiyolojik patojenin virulansı, enfekte dokunun yapısı, enfeksiyon geçiş yolu, enfeksiyonun ortaya çıkış süresi ve konağın komorbid faktörlerine (sistemik faktörler) bağlı olarak değişebilmektedir.
Nowadays periprosthetic joint infections have become more prevalent parallel to the increasing number of arthroplasty operations. In the treatment of periprosthetic joint infections; some treatment modalities like irrigation and debridement, antibiotherapy, single or two-staged revisions are common practice. However, in failed cases with this treatment modalities, surgeons should bear in mind that using non-implantation treatment methods according to the duration of infection, the period of symptoms, the virulence of the pathogen, the status of the joint (bone loss or soft tissue problems etc.), the expectations of patient, immune status and comorbid factors of the patient (renal insufficiency, hepatic insufficiency, immunodeficiency, peripheral arterial disease etc.). Surgeons should consider that selection of the patients is the main factor in the success of these treatments.

Key words: long-term antibiotic suppression; resection arthroplasty; arthrodesis intercalary prosthesis; amputation

Periprostetik eklem enfeksiyonları, mikroorganizmaların protez materyali üzerinde biyofilm tabakası üretmesi ve mikroorganizmaların osteoblast hücre duvarını geçebilmesi nedeniyle, tedavisi güç bir klinik problemdir. ${ }^{[5]}$ Mikroorganizmaların protez materyali ile temasına bağlı adhezyonu sonrası, üretilen biyofilm tabakası ve stafilokok gibi spesifik bazı bakterilerin konak hücreleri içerisine yerleşmesiyle, bu patojenlerin antibiyoterapinin etkisinden korunabilmelerini sağlamaktadır. ${ }^{[6,7]}$

Periprostetik eklem enfeksiyonlarının tanı ve tedavisinde, bir algoritmaya göre hareket edilmesi önerilmektedir. ${ }^{[8]}$ PEE'lerin tanısında klinisyenlere yardımcı olması amaciyla, AAOS ve International Consensus Grubu tarafından, tanıda izlenmesi gereken algoritmalar yayımlanmıştır. ${ }^{[9,10,11]}$ Buna göre, serum enfeksiyon marker'larının (CRP, eritrosit sedimentasyon

- Illetişim adresi: Prof. Dr. Cengiz Şen, İstanbul Üniversitesi İstanbul Tıp Fakültesi, Ortopedi ve Travmatoloji Ana-bilim Dalı, Millet Caddesi 34390 Çapa, Fatih, İstanbul Tel: 0532 - 2456365 e-posta: senc64@gmail.com

- Geliș tarihi: 1 Mart $2016 \quad$ Kabul tarihi: 1 Mart 2016 
hızı) incelenmesi ve eklem aspirasyonu yapılması gereklidir; elde edilen eklem sıvısında lökosit sayımı, nötrofil oranı, lökosit esteraz ve kültür antibiyogram yapılmalıdır. Kültürde üreme elde edilemeyen hastalarda, klinik bulgulara paralel olarak aspirasyon tekrarlanabilir. Bu hastalarda, antibiyoterapinin en az 14 gün önce kesilmiş olmasına dikkat edilmelidir. Tekrarlanan aspirasyonlara rağmen enfeksiyon tanısı konusunda şüphede kalınan olgularda; lökosit işaretli kemik sintigrafisi, spesifitesi düşük olmasına rağmen kullanılabilir. Tanı konulamayan sınırlı hasta grubunda; tru-cut, punch biyopsi, açık biyopsi veya artroskopik olarak alınan dokuların incelenmesi de gerekli olabilir. Bunun yanında, PEE tanısında procalcitonin ve interlökin-6 gibi serum marker'larının kullanımı halen tartışmalıdır. ${ }^{[12]}$ Kas İskelet Sistemi Enfeksiyon Birliği tarafından, periprostetik enfeksiyon tanımı yapılmıştır. ${ }^{[13]} 2011$ yılında yayımlanan bu kılavuza göre; protez ile ilişkili bir bölgede fistül olması ve ayrı seanslarda alınan doku ya da sıvı örnekleri kültürlerinde aynı patojenin üremesi, PEE olarak tanımlanmıştır. Bunun dışında, minör kriterler olarak tanımlanan; 1) artmış ESR ve CRP değerleri varlığı, 2) sinoviyal sıvıda artmış lökosit sayısı, 3) sinoviyal sıvıdaki nötrofil oranında artış olması, 4) etkilenen eklemde pürülan mai olması, 5) tek bir doku ya da sıvı kültür örneğinde üreme elde edilmesi ve 6) protez çevresinden alınan dokuda beşten fazla lökosit görülmesi kriterlerinden en az üçünün pozitif olduğu klinik durumlarda, PEE tanısı konulabileceği bildirilmiştir.

Periprostetik eklem enfeksiyonu tedavisinde birçok yöntem tarif edilmiş ve tedavide uygulanmaktadır. Bunlar; irrigasyon-debridman, antibiyoterapi, tek basamaklı revizyon, iki basamaklı-revizyon ve alternatif (implantasyon dışı, kurtarıcı) prosedürler (kronik antibiyotik baskılaması, rezeksiyon artroplastisi, artrodez, ampütasyon) olarak sıralanabilir. ${ }^{[5,10]}$

PEE tedavisinde; enfeksiyonun gelişim süreci, semptomların süresi, etken organizmanın virulansı, eklemin genel durumu (kemik kaybı ya da eklem üzerini örten yumuşak dokudaki yetersizlikler vb.), hastanın beklentisi, hastanın bağışıklık durumu ve komorbid faktörleri (karaciğer yetmezliği, böbrek yetmezliği, pulmoner yetmezlik, kronik malnütrisyon, diyabetes mellitus, immünsupresyon, ekstremitenin vasküler problemleri vb.) gibi hastaya ait faktörlere göre karar verilmelidir. Cerrah, hastanın tedavisi için tüm bu faktörleri göz önünde bulundurmalı ve ona göre karar vermelidir. ${ }^{[5,10,12]}$

Sink ve arkadaşları tarafından, kalça cerrahisi sonrasında gelişen komplikasyonlar, ardından Lorio ve arkadaşları tarafindan, total diz protezi sonrasında gelişebilecek komplikasyonlar sınıflandırılmış ve tedavisi açısından bir algoritma önerilmiştir. ${ }^{[14,15]}$ Buna göre, Grade 1'den Grade 5'e kadar bir sınıflandırma geliştirilmiştir. Bu sınıflamaya göre; hayatı tehdit edici, yoğun bakım yatışı gerektirecek, geçici sakatık ile tedavi edilemeyecek, rezeksiyon artroplastisi, artrodez ya da ampütasyon gerektirecek hastalar olan Grade 4 enfeksiyon komplikasyonlarında, alternatif (implantasyon dışı, kurtarıcı) tedavi yöntemleri (kronik antibiyotik baskılaması, rezeksiyon artroplastisi, artrodez, interkalar protez, ampütasyon) önerilmektedir. Alternatif ya da kurtarıcı olarak da isimlendirilebilecek bu girişimler; tekrarlayan PEE'leri olan, fonksiyonel olarak tekrar implantasyon uygulanma ihtimali düşük, immün yetmezlik ya da kronik hastalıkları yüzünden tekrarlayan cerrahilere uygun olmayan hastalarda, göz önünde bulundurulmalıdır.

\section{UZUN DÖNEM ANTIBIYOTIK BASKILAMASI}

Antibiyotik baskılamasındaki amaç, enfeksiyonun eradikasyonundan çok, kontrol altına alınmasıdır. Antibiyotik baskılaması, iki aşamalı revizyon ile tekrar implantasyon yapılmış olan, fakat inflamasyon bulguları halen devam eden hastalarda uygulanabilmektedir. Buna rağmen, uzun dönem antibiyotik baskılaması, bu hastalarda tartışmalı bir konudur. ${ }^{[16]}$

Uzun dönem antibiyotik baskılaması için ideal hasta grubu; enfekte protez materyallerinin çıkarılamadığı, cerrahi tedavi istemeyen hastalar ya da cerrahi tedaviyi kaldıramayacak kadar düşkün hastalardır. Bu tedavi; protezin kemiğe iyi tutunduğu, üretilen patojenin virulansının zayıf ve patojene etkili uygun oral antibiyoterapinin mevcut olduğu hastalarda tercih edilmelidir. Bu endikasyonlarla tedavi edilen 36 enfekte diz protezi hastasının sunulduğu bir çalışmada, beş yıllık takip sonrasında, antibiyotik baskılaması sonrası \%86 başarı bildirilmiştir. ${ }^{[17]}$ Buna rağmen, literatürdeki bazı çalışmalarda, bu tedavi başarısının \%18-24'lere kadar düştüğünü görmekteyiz. ${ }^{[18,19]} \mathrm{Bu}$ durumda tedavinin başarılı olması için, hasta seçimi çok önem taşımaktadır.

Uzun dönem antibiyotik baskılaması açısından kontrendikasyon; vücutta başka bir bölgede implant bulunması ya da kalp kapak replasmanı bulunmasıdır. Ayrıca, uzun dönem antibiyotik baskılaması yapılan hastalar, enfeksiyon hastalıkları tarafından karaciğer ve böbrek fonksiyonları açısından düzenli gözlem altında tutulmalıdır. Uzun dönem antibiyotik supresyonunda sık kullanılan antibiyotik rejimleri ve patojenler, Tablo 1'de özetlenmiştir. 
Tablo 1. Uzun dönem oral antibiyotik tedavisinde sık uygulanan antibiyotik rejimleri ${ }^{[16]}$

\begin{tabular}{|c|c|c|}
\hline Mikroorganizma & Tercih edilen tedavi & Alternatif tedavi \\
\hline Stafilokok, oksasilin duyarlı & $\begin{array}{l}\text { Cephalexin } 500 \mathrm{mg} \text { PO, } 2 \times \text { ya da } 4 \times \\
\text { Cefadroxil } 500 \mathrm{mg} \text { PO, } 2 \times\end{array}$ & $\begin{array}{l}\text { Dicloxacilin } 500 \text { mg PO, } 3 \times \text { ya da } 4 \times \\
\text { Klindamisin } 300 \text { mg PO, } 4 \times \\
\text { Amoksisilin-klavulanat } 500 \text { mg PO, 3× }\end{array}$ \\
\hline Stafilokok, oksasilin dirençli & $\begin{array}{l}\text { Kotrimaksazol DS tb PO, } 2 \times \\
\text { Minoksiklin ya da doksisiklin } 100 \text { mg PO, 2× }\end{array}$ & \\
\hline$\beta$-Hemolitik streptokok & $\begin{array}{l}\text { Penisilin V } 500 \text { mg PO, } 2 \times \text { ya da } 4 \times \\
\text { Amoksisilin } 500 \text { mg PO, 3× }\end{array}$ & Cephalexin 500 mg PO, $3 \times$ ya da $4 \times$ \\
\hline Enterococcus spp, penisilin duyarlı & $\begin{array}{l}\text { Penisilin V } 500 \text { mg PO, 2× ya da } 4 \times \\
\text { Amoksisilin } 500 \text { mg PO, 3× }\end{array}$ & \\
\hline Pseudomonas aeruginosa & Siprofloksasin 250-500 mg PO, 2× & \\
\hline Enterobacteriaceae & Kotrimaksazol 1 DS tb PO & In-vitro duyarlılıkta $\beta$-Laktam oral tedavi \\
\hline Propionibacterium spp & $\begin{array}{l}\text { Penisilin V } 500 \text { mg PO, 2× ya da } 4 \times \\
\text { Amoksisilin } 500 \text { mg PO, 3× }\end{array}$ & $\begin{array}{l}\text { Cephalexin } 500 \text { mg PO, } 3 \times \text { ya da } 4 \times \\
\text { Minoksiklin ya da doksisiklin } 100 \text { mg PO, } 2 \times\end{array}$ \\
\hline
\end{tabular}

\section{REZEKSIYON ARTROPLASTISI}

Yeni bir implant yerleştirilmeden enfekte materyallerin çıkarılması ve agresif olarak dokuların debridmanı işlemi, rezeksiyon artroplastisi olarak adlandırılır. Rezeksiyon artroplastisi için endikasyonlar; yetersiz kemik ve yumuşak doku kalitesi, özellikle dirençli bakterilerle gelişen tekrarlayan periprostetik eklem enfeksiyonları ve birçok başarısız revizyon geçiren, düşük fonksiyonel beklentili hastalardır.

Diz protezi enfeksiyonlarında bu tekniğin dezavantajı; dizde yarattığı instabilite, bacak boyu eşitsizliği, fonksiyonel bozukluk ve buna eşlik eden yüksek hasta memnuniyetsizliğidir. Buna rağmen, Wasielewski ve arkadaşları, rezeksizyon artroplastisi uyguladıkları 76 enfekte diz protezinden 69'unda (\%90) enfeksiyon eradikasyonu sağladıklarını bildirmişlerdir. ${ }^{[20]}$

Rezeksiyon artroplastisi, tarihsel süreç içerisinde, özelikle 1960'lar ve 1970'lerde, cup artroplastisi gibi başarısız tüm artroplastiler için uygulanmış bir tedavi yöntemidir. ${ }^{[21]}$ Enfekte kalça protezlerinde rezeksiyon artroplastisi uygulanan 78 hastalık bir seride, hastaların \%86'sında enfeksiyonun kontrol altına alındığı bildirilmiştir. Yine bu çalışmada, hastalarda ortalama $4,1 \mathrm{~cm}$ ekstremite kısalık farkı gelişmesi bildirilmesine rağmen, bunun fonksiyonel etkisi üzerinde durulmamıştır. ${ }^{[22]} \mathrm{Bu}$ konuda, Kantor ve arkadaşları, rezeksiyon artroplastisi uyguladıkları 39 hastanın 41 enfekte kalça protezini değerlendirdikleri çalışmalarında, hastaların son kontrollerinde $\% 39$ oranında enfeksiyonun kontrol altına alınamadığı, bunun yanı sıra \%83'ünün mobilizasyonunun oldukça sınırlı olduğu ya da mobilize olamadığı ve sadece iki hastanın yardımcı cihaz olmaksızın son kontrollerde mobilize olabildiğini bildirmişlerdir. ${ }^{[23]}$

Tek basamaklı ya da iki basamaklı tedavilere rağmen başarı sağlanamayan, enfeksiyonun devam ettiği hastalarda, mantar enfeksiyonu düşünülmelidir. Bu açıdan, debridmanlar esnasında bu hastalardan mantar kültürleri alınmalıdır. Mantar enfeksiyonu tespit edilmiş ya da çok sayıda cerrahi tedavi geçirmiş hastalarda, enfeksiyonun yüksek nüks riski nedeniyle de, rezeksiyon artroplastisi iyi bir tedavi alternatifi olarak öne çıkmaktadır (Şekil 1).

Sonuç olarak, PEE'lerin rezeksiyon artroplastisi ile tedavisinde, literatürde değişken sonuçlar bildirilmiştir. Buna rağmen, uygulanan debridmanın kalitesiyle birlikte değişken oranlar bulunduğu halde, rezeksiyon artroplastisi ile ortalama enfeksiyon eradikasyonu oranının \%80'lerde olduğu, ayrıca hastaların yürümeye yardımcı brace ya da koltuk değnekleri ile fonksiyonel kapasitelerinde gerileme olsa da, \%80'e varan oranlarda mobilize olabildikleri bildirilmektedir. ${ }^{[8,24]}$ Rezeksiyon artroplastisi sonrası enfekte ajanın izolasyonu ve kültür antibiyogramının rehberliğinde uygun antibiyotik tedavisinin devamı, enfeksiyon eradikasyonunun önemli bir diğer parçasıdır. Özetle; rezeksiyon artroplastisi, enfeksiyonun kontrol altına alınamadığı ağrılı PEE'lerde tercih edilebilecek bir kurtarıcı implantasyon dışı tedavi seçeneği olarak kabul edilmektedir (Şekil 2). 

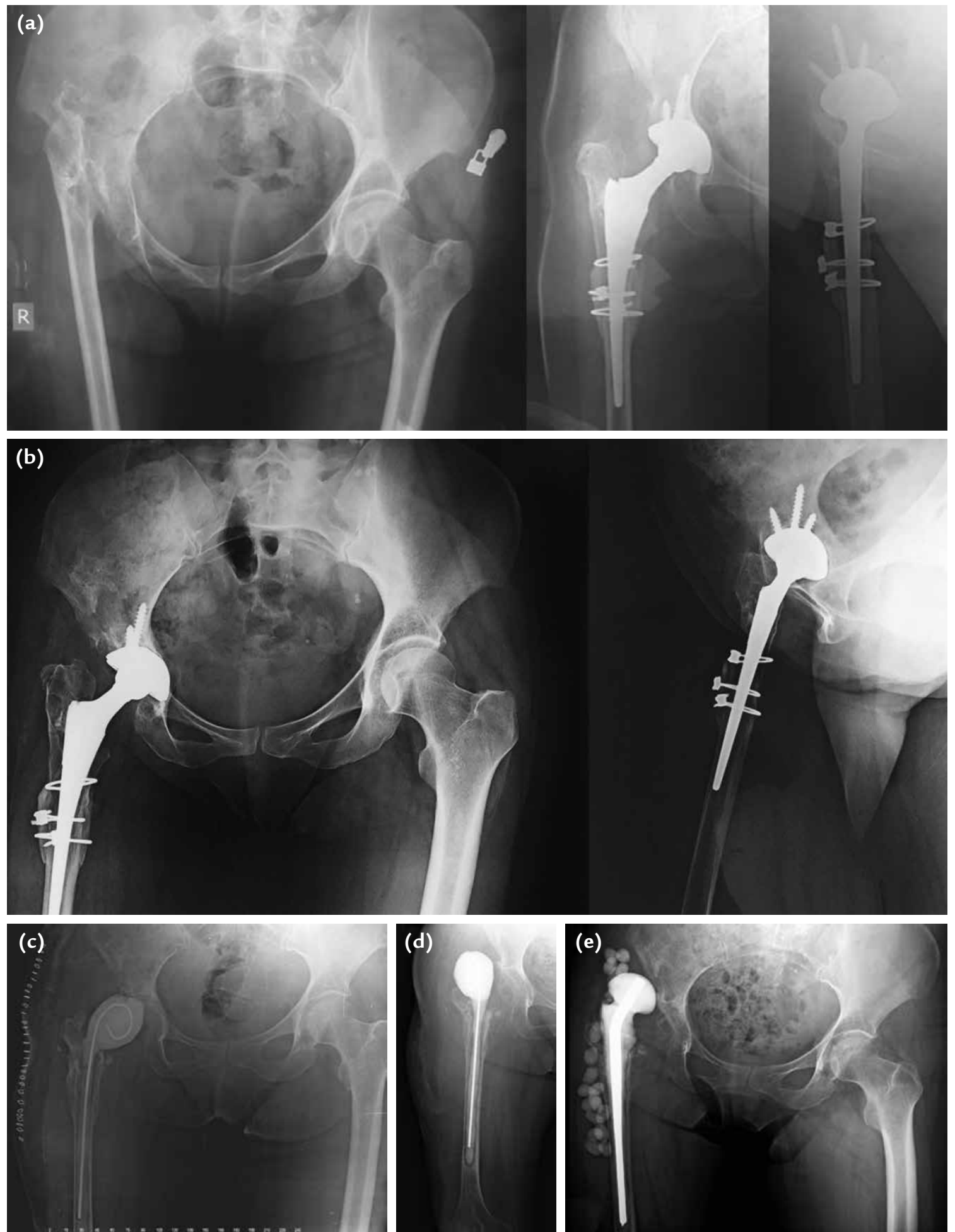

Şekil 1. a-e. Altmış iki yaşında envetere gelişimsel kalça displazisi nedeniyle sağ kalça kısaltmalı protez operasyonu uygulanmış hastanın erken dönem grafileri (a). Geç dönem protez enfeksiyonu tanısı sonrası, hastada enfekte gevşeme bulguları tespit edilen grafiler görülmekte (b). Enfekte protez materyallerinin çıkarılması sonrasındaki radyolojik görünüm (c). Hastadan cerrahi öncesi alınan kültürler neticesinde, metisilin dirençli S.aureus ve E.coli üremesi tespit edildi. Uygun antibiyoterapisi düzenlenen hastanın akıntısının devam etmesi sonrası, antibiyotikli spacer revizyonu planlandı. Spacer revizyonu öncesi radyolojik görünümü (d). Hastanın spacer revizyonu sırasında alınan kültürlerinde mantar enfeksiyonu tespit edilmesi sonrasında, hastaya targocidli antibiyotikli spacer ve amfoterasin-B'li zincir uygulandı. Enfeksiyon tedavisi tamamlanan hastanın son kontrol grafileri izlenmekte (e). 

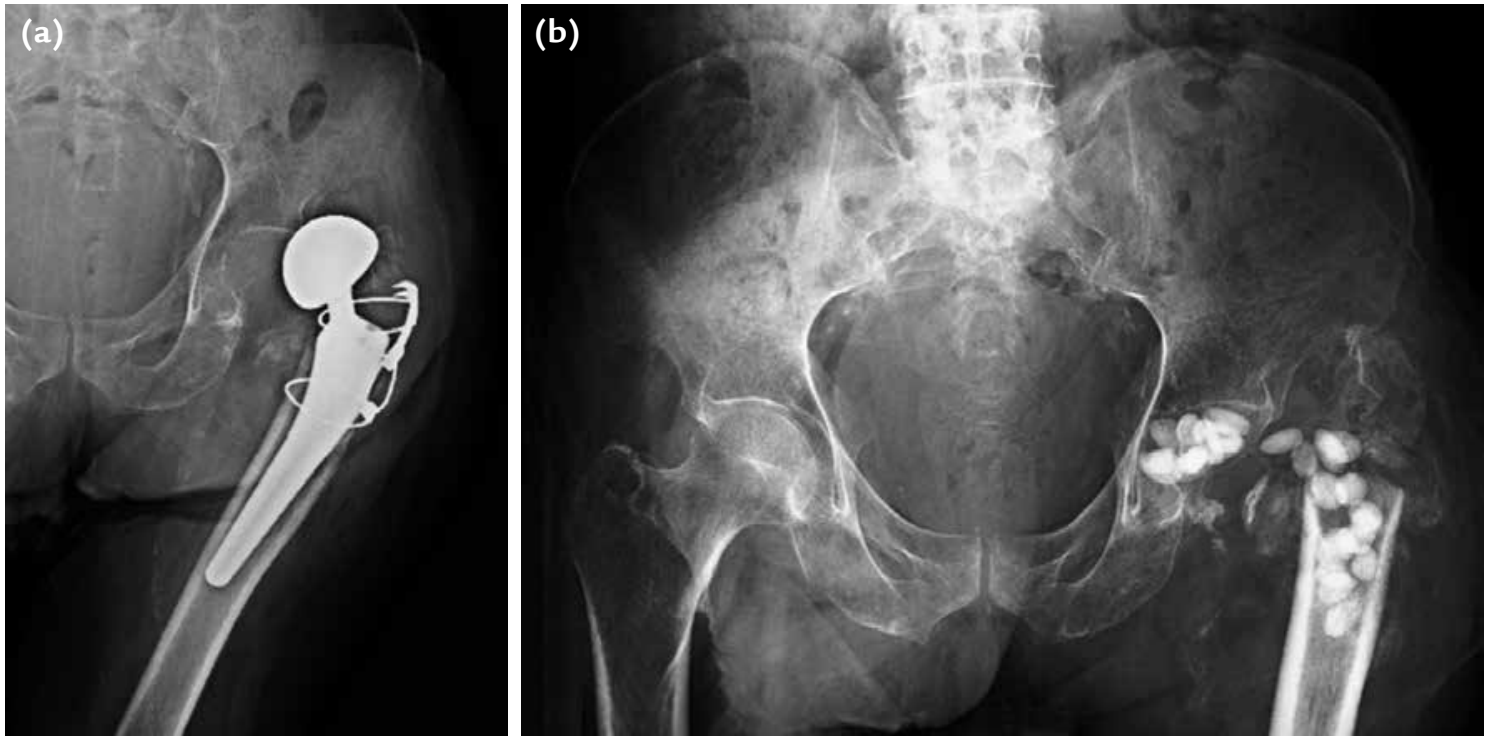

Şekil 2. a, b. Seksen bir yaşındaki erkek hastanın sol kalça grafisi izlenmekte. Hastaya sol kalça enfekte protez luksasyonu için; hastanın kronik böbrek yetmezliği, periferik arter hastalığı, kardiyak ve göğüs hastalıkları açısından yüksek riskli olması ve tekrarlayan operasyonlara uygun olmaması nedeniyle, rezeksiyon artroplastisi uygulandı (a). Hastanın cerrahi sonrası 1. yıldaki pelvis AP grafisi (b).

\section{ARTRODEZ}

Artrodez, PEE'lerde geleneksel tedavi yöntemlerinden biridir. Geçtiğimiz son on yıl içerisinde uygulanan başarılı tek ya da iki aşamalı revizyonlar sayesinde, PEE sonrasında uygulanan artrodez sayıları giderek azalmıştır. ${ }^{[8]}$ Artrodez açısından uygun hastalar; rekonstrüksiyon girişimleri başarısızlıkla sonuçlanmış, özellikle ekstansör mekanizma kaybı ya da kemik stoğu kaybı olan, dirençli patolojenlerin kültürde üretildiği genç aktif PEE olan hastalardır.

Enfekte diz artroplastisi sonrası uygulanan artrodezlerde, değişik teknikler kullanılabilmektedir. Bunlar; eksternal fiksasyon, çift plaklama, intramedüller çivi ile artrodez olarak sıralanabilir. ${ }^{[12]}$ Artrodez için tek ya da iki aşamalı cerrahi uygulanabilir. Artrodez sonrasında; enfeksiyonun tekrarlaması, ağrı, bacak boyu eşitsizliği ve rotasyonel deformite gibi komplikasyonlar bildirilmiştir. ${ }^{[25]}$ PEE sonrasında tek aşamalı ve iki aşamalı artrodezlerin karşılaştırıldığı bir derlemede, iki aşamalı artrodezler hakkında daha fazla güvenli veri olmasına rağmen, aralarında fark olduğuna dair bilimsel bir kanıt olmadığı bildirilmiştir. ${ }^{[26]}$ Literatürde, değişik tekniklerle uygulanan artrodezler sonrası \%75-94 arasında değişen klinik başarı bildirilmiştir. ${ }^{[27-29]}$ Literatürde, eksternal fiksasyon ve intramedüller çivi ile artrodezi karşılaştıran çalışmalarda, enfeksiyon nüksü açısından, eksternal fiksatör kullanımının avantajlı olduğu bildirilmiştir. Buna rağmen, kaynama oranları açısından yapılan değerlendirmelerde, intramedüller teknikle artrodez daha başarılı olarak öne çıkmaktadır. ${ }^{[27,30]}$ Kliniğimizde, enfekte diz protezi sonrası monoplanar eksternal fiksatör ile artrodez uyguladığımız 17 hastanın klinik sonuçlarını değerlendirdik. Tamamında iki aşamalı tedavi uyguladığımız hastalarımızın, biri hariç tamamında (\%94) kaynama elde ettik. Ortalama kaynama süresi 6,8 ay olan hasta grubumuzda, ortalama bacak boyu eşitsizliği 2,9 cm'ydi. ${ }^{[31]}$ Literatürde, diz protezi enfeksiyonu sonrasında iki aşamalı revizyona rağmen enfeksiyon nüksü olan hastalarda, artrodez, sınırlı fonksiyonel düzelme de sağlayan ideal tedavi alternatifi olarak öne çıkmaktadır (Şekil 3 ve 4). ${ }^{[32]}$

Enfekte kalça artroplastisi sonrası artrodezin, sınırlı bir klinik kullanımı mevcuttur. Kalça PEE'lerde kurtarıcı bir işlem olarak artrodez; plak gerektirmesi, ciddi kemik defektleri ve teknik problemler nedeniyle, alternatif antibiyotik supresyonuna göre daha az tercih edilmektedir. Bu konuda literatürde, Kostuik ve arkadaşlarının 1984 yılında yayımladıkları bir yayın bulunmaktadır. ${ }^{[33]}$ Yazarlar, 14 hastalık serilerinde, yedi enfekte kalça protezinin dördü için tek basamaklı, üçü için iki basamaklı tedavi uygulamışlar ve 14 hastanın 13'ünde başarılı füzyon elde ettiklerini bildirmişlerdir. Yazarlar, tek taraflı başarısız kalça artroplastisi olan hastalarda artrodez önermişlerdir. ${ }^{[33]}$ 

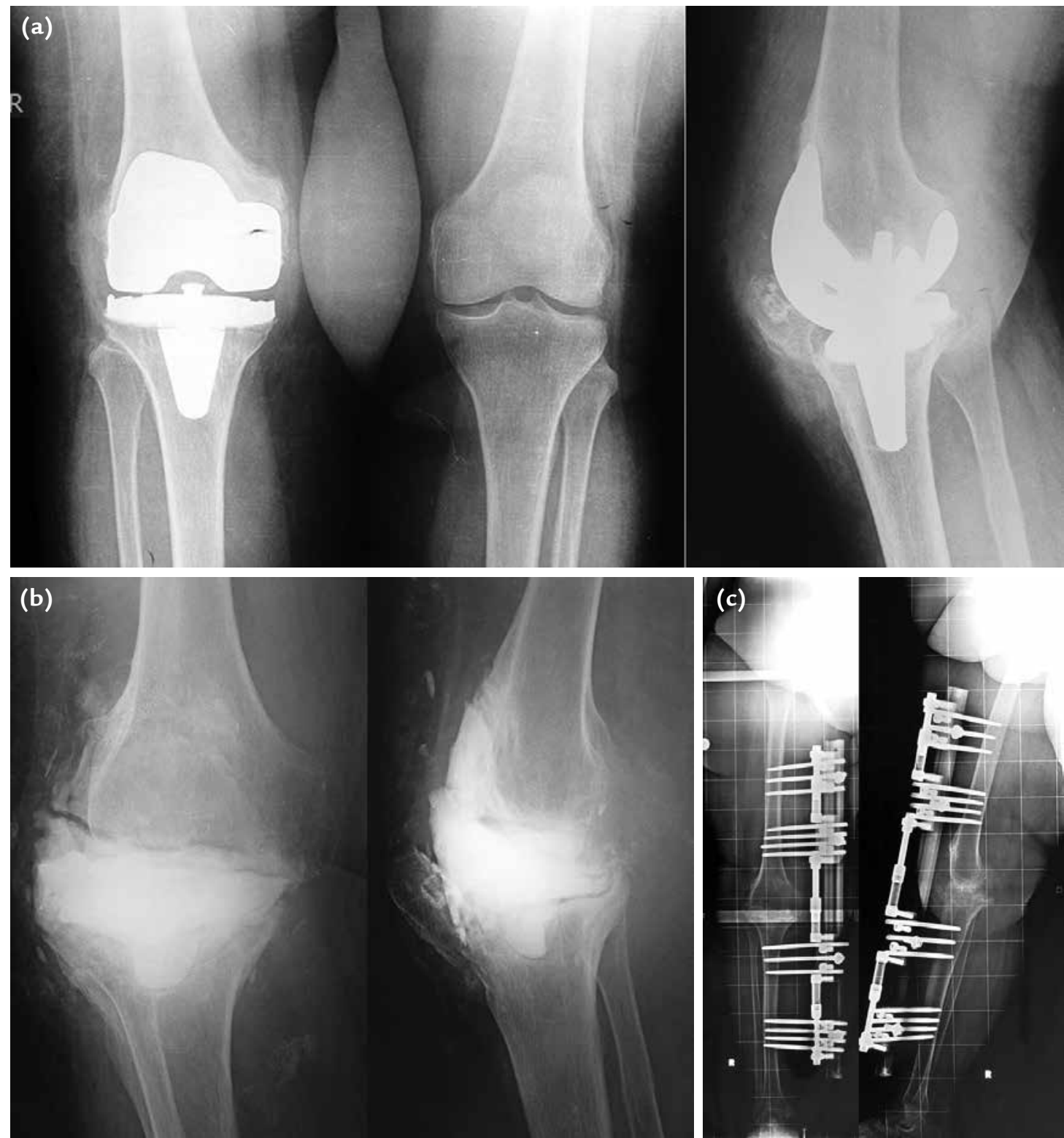

(d)

Şekil 3. a-d. Altmış sekiz yaşındaki bayan hastanın sağ dizindeki enfekte protezin radyolojik görünümü (a). Ekstansör mekanizma problemi de olan hastanın, protez çıkarma sonrasındaki antibiyotik spacer'lı radyolojik görüntüsü (b). Hastaya 2. basamakta monoplanar eksternal fiksatör ile uygulanan artrodezin radyolojik görünümü (c). Hastanın cerrahi sonrası 1. yıldaki füzyon sağlanmış düz grafileri görülmekte (d). 

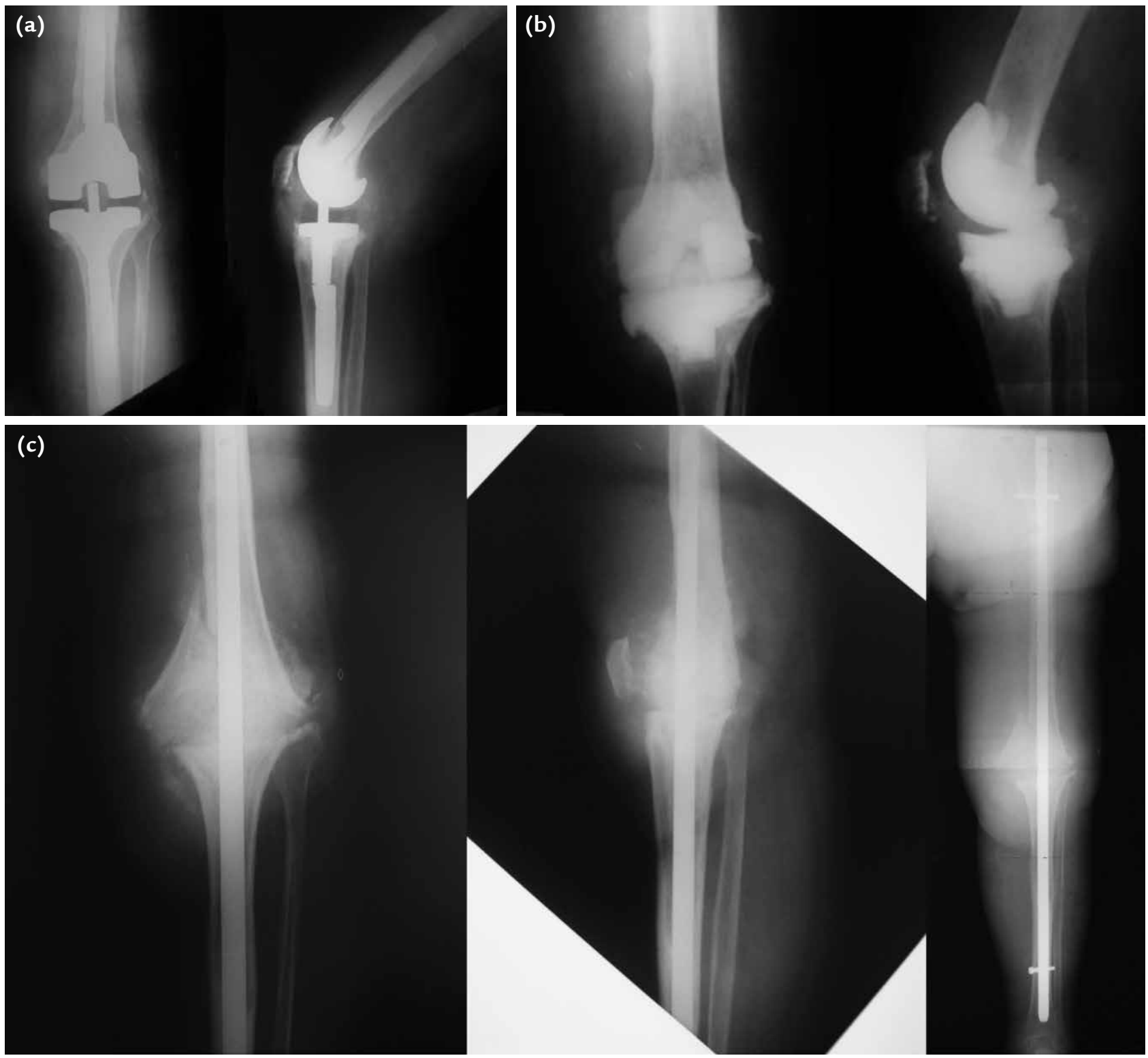

Şekil 4. a-c. Altmış yaşında bayan hastanın enfekte sol diz protezine ait grafileri görülmekte (a). Hastanın enfekte protez materyallerinin çıkarılması sonrasında, antibiyotikli spacer uygulanmış grafileri görülmekte (b). Enfeksiyon tedavisi sonrasında, hastaya özel üretilmiş intramedüller çivi ile artrodez operasyonu uygulandı (c).

\section{INTERKALAR PROTEZ UYGULAMALARI}

Enfekte diz protezlerinin tedavisinde az kullanılan bir diğer alternatif tedavi, interkalar protez uygulamalarıdır. ${ }^{[34,35]}$ Interkalar protez uygulamaları, özellikle çok ciddi miktarda kemik defekti olan ve bu nedenle artrodez sonrasında ciddi kısalık kalacak ya da eşlik eden ekstansör mekanizma problemi olan hastalarda tercih edilmektedir. Çok kısıtlı sayıda hasta için uygun bir tedavidir ve hastalarda kemik kaynaması beklenilmeden, dizde kaynama gerektirmeyen bir implant ile stabilite sağlanabilir. Bu hastalarda, transfemoral ampütasyona kıyasla, interkalar protez uygulamaları ile ekstremitenin korunması ve daha iyi bir fonksiyonel sonuç elde edilebilir (Şekil 5). ${ }^{[35]}$

\section{AMPÜTASYON}

Diz üstü ampütasyon, enfekte diz artroplastisi sonrasında son seçenek olarak karşımıza çıkan bir kurtarıcı cerrahidir. Çok nadir endikasyonu olmakla birlikte, 

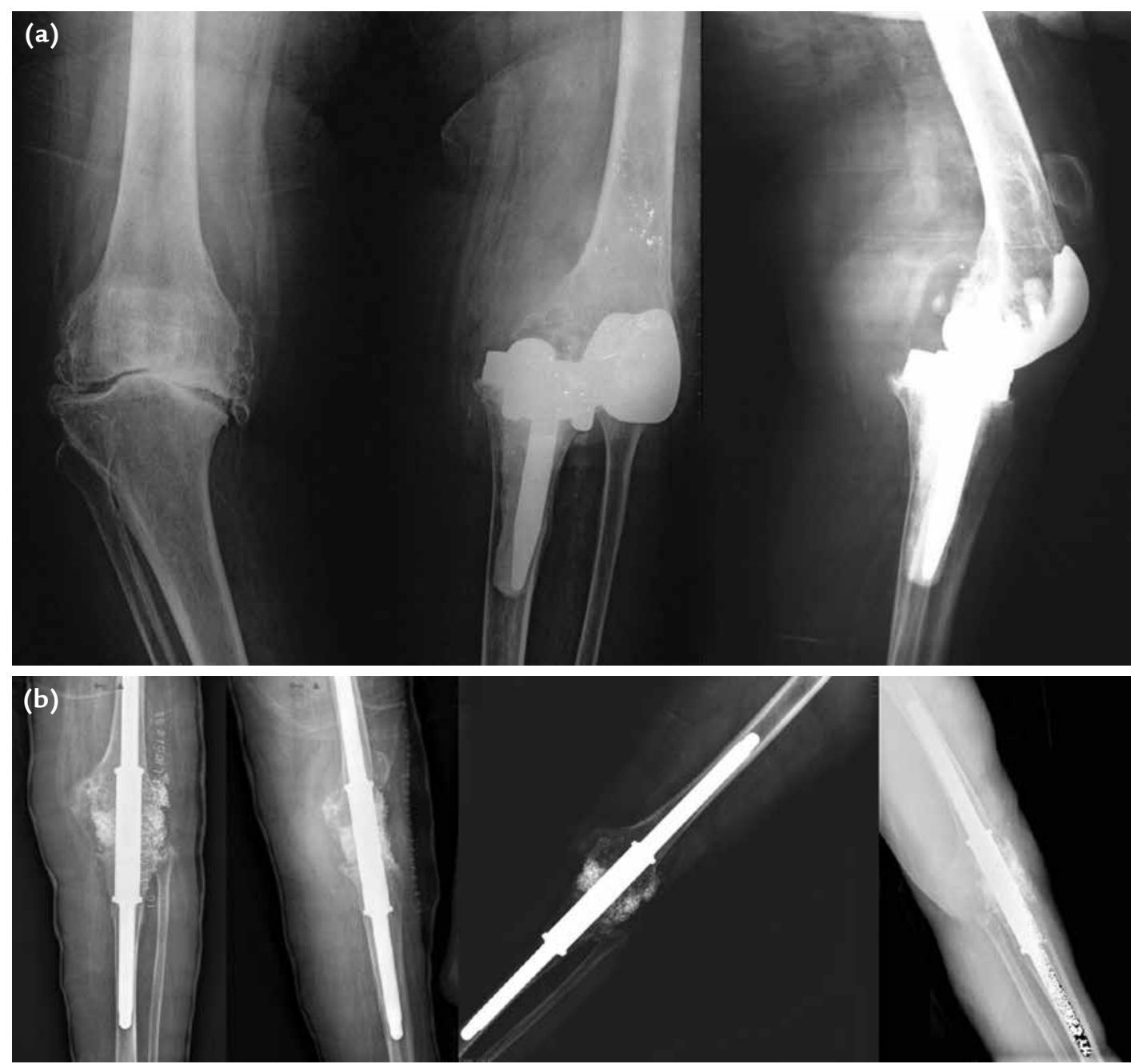

Şekil 5. a, b. Sol diz enfekte protez luksasyonu nedeniyle kliniğimize başvuran hastanın grafileri görülmekte (a). Enfekte materyallerin çıkarılması sonrasında sol diz interkalar protez uygulaması yapılan hastanın grafileri görülmekte (b).

özellikle hayatı tehdit eden sistemik sepsiste endikasyonu bulunmaktadır. Fakat bunun dışında, ciddi yumuşak doku enfeksiyonunun eşlik ettiği PEE'nda, masif kemik kayıplarında, çok kez denenmesine rağmen alternatif tedavilerin başarısız olduğu inatçı enfeksiyon nükslerinde gerekli olabilmektedir. ${ }^{[36]}$

Sierra ve arkadaşlarının, 18.443 diz protezini değerlendirildiği çalışmalarında, hastaların 19'unda $(\% 0,1)$, periprostetik enfeksiyonun kontrol altına alınamaması nedeniyle ampütasyon uygulandığı ve bu hastalarda fonksiyonel sonuçların ise oldukça kötü olduğu bildirilmiştir. ${ }^{[36]}$

Enfekte diz protezi sonrası kurtarıcı cerrahi tedavi olarak diz-üstü ampütasyon ve artrodezin karşılaştırıldığı geriye dönük çalışmada, artrodez ile tedavi edilen 20 hasta ile ampütasyon uygulanmış altı hasta karşılaştırılmıştır. Yazarlar, sonuç olarak, artrodez hastalarında fonksiyonel ve bağımsız hareket kabiliyeti açısından daha iyi sonuç elde edildiğini bildirmişlerdir. ${ }^{[37]}$

\section{SONUÇ}

Periprostetik eklem enfeksiyonlarındaki artış nedeniyle, ileriki yıllarda cerrahlar ve klinisyenler, bu tedavisi güç problemle daha fazla karşılaşacaklardır. Enfeksiyon önlemlerine dikkat edilmesine rağmen gelişen enfeksiyonlarda; önerilen algoritmalar içinde hareket edilmeli, başarısız olunan seçilmiş hastaların tedavisinde, implantasyon dışı tedavi yöntemleri farklı ve başarılı seçenekler olarak akılda tutulmalıdır. 


\section{KAYNAKLAR}

1. KurtzS, Ong K, Lau E, MowatF, Halpern M. Projections of primary and revision hip and knee arthroplasty in the United States from 2005 to 2030. J Bone Joint Surg Am 2007;89(4):780-5.

2. Yıldız F, Tuncay I. Enfekte Protez Revizyonu. Turkiye Klinikleri J Orthop \& Traumatol-Special Topics 2014;7(3):64-9.

3. Kurtz SM, Ong KL, Schmier J, Mowat F, Saleh K, Dybvik E, Kärrholm J, Garellick G, Havelin LI, Furnes O, Malchau H, Lau E. Future clinical and economic impact of revision total hip and knee arthroplasty. J Bone Joint Surg Am 2007;89 Suppl 3:144-51.

4. Fitzgerald RH Jr, Nolan DR, Ilstrup DM, Van Scoy RE, Washington JA 2nd, Coventry MB. Deepwound sepsis following total hip arthroplasty. J Bone Joint Surg Am 1977;59(7):847-55.

5. Lima AL, Oliveira PR, Carvalho VC, Saconi ES, Cabrita HB, Rodrigues MB. Periprosthetic joint infections. Interdiscip Perspect Infect Dis 2013;2013:542796. Crossref

6. Hudson MC, Ramp WK, Frankenburg KP. Staphylococcus aureus adhesion to bone matrix and bone-associated biomaterials. FEMS Microbiol Lett 1999;173(2):279-84.

7. Wright JA, Nair SP. Interaction of staphylococci with bone. Int J Med Microbiol 2010;300(2-3):193-204. Crossref

8. Springer BD, Pavizi J. Periprosthetic Joint Infection of Hip and Knee. New York: Springer; 2014.

9. American Academy of Orthopaedic Surgeons. The diagnosis of periprosthetic joint infections of the hip and knee. Guideline and Evidence Report. Rosemont, IL: American Academy of Orthopaedic Surgeons (AAOS); 2010. p.286.

10. Parvizi J, Adeli B, Zmistowski B, Restrepo C, Greenwald AS. Management of periprosthetic joint infection: the current knowledge: AAOS exhibit selection. J Bone Joint Surg Am 2012;94(14):e104. Crossref

11. Parvizi J, Gehrke T, Chen AF. Proceedings of the International Consensus on Periprosthetic Joint Infection. Bone Joint J 2013;95-B(11):1450-2. Crossref

12. Gehrke $T$, Alijanipour $P$, Parvizi J. The management of an infected total knee arthroplasty. Bone Joint J 2015;97-B(10 Suppl A):20-9. Crossref

13. Parvizi J, Zmistowski B, Berbari EF, Bauer TW, Springer BD, Della Valle CJ, Garvin KL, Mont MA, Wongworawat MD, Zalavras CG. New definition for periprosthetic joint infection: from the Workgroup of the Musculoskeletal Infection Society. Clin Orthop Relat Res 2011;469(11):2992-4. Crossref

14. Sink EL, Leunig M, Zaltz I, GilbertJC, ClohisyJ; Academic Network for Conservational Hip Outcomes Research Group. Reliability of a complication classification system for orthopaedic surgery. Clin Orthop Relat Res 2012;470(8):2220-6. Crossref

15. Iorio R, Della Valle CJ, Healy WL, Berend KR, Cushner FD, Dalury DF, Lonner JH. Stratification of standardized TKA complications and adverse events: a brief communication. Clin Orthop Relat Res 2014;472(1):194-205. Crossref

16. Osmon DR, Berbari EF, Berendt AR, Lew D, Zimmerli W, Steckelberg JM, Rao N, Hanssen A, Wilson WR; Infectious Diseases Society of America. Diagnosis and management of prosthetic joint infection: clinical practice guidelines by the Infectious Diseases Society of America. Clin Infect Dis 2013;56(1):e1-25. Crossref

17. Rao N, Crossett LS, Sinha RK, Le Frock JL. Long-term suppression of infection in total joint arthroplasty. Clin Orthop Relat Res 2003;(414):55-60.

18. Bengtson $\mathrm{S}$, Knutson $\mathrm{K}$. The infected knee arthroplasty. A 6-year follow-up of 357 cases. Acta Orthop Scand 1991;62(4):301-11.
19. Hanssen AD, Rand JA. Evaluation and treatment of infection at the site of a total hip or knee arthroplasty. Instr Course Lect 1999;48:111-22.

20. Wasielewski RC, Barden RM, Rosenberg AG. Results of different surgical procedures on total knee arthroplasty infections. J Arthroplasty 1996;11(8):931-8.

21. Haw CS, Gray DH. Excision arthroplasty of the hip. J Bone Joint Surg Br 1976;58(1):44-7.

22. Castellanos J, Flores $X$, Llusà $M$, Chiriboga $C$, Navarro $A$. The Girdlestone pseudarthrosis in the treatment of infected hip replacements. Int Orthop 1998;22(3):178-81.

23. Kantor GS, Osterkamp JA, Dorr LD, Fischer D, Perry J, Conaty JP. Resection arthroplasty following infected total hip replacement arthroplasty. J Arthroplasty 1986;1(2):83-9.

24. Ballard WT, Lowry DA, Brand RA. Resection arthroplasty of the hip. J Arthroplasty 1995;10(6):772-9.

25. Röhner E, Windisch C, Nuetzmann K, Rau M, Arnhold M, Matziolis G. Unsatisfactory outcome of arthrodesis performed after septic failure of revision total knee arthroplasty. J Bone Joint Surg Am 2015;97(4):298-301. Crossref

26. Masters JP, Smith NA, Foguet $P$, Reed $M$, Parsons $H$, Sprowson AP. A systematic review of the evidence for single stage and two stage revision of infected knee replacement. BMC Musculoskelet Disord 2013;14:222. Crossref

27. Mabry TM, Jacofsky DJ, Haidukewych GJ, Hanssen AD. Comparison of intramedullary nailing and external fixation knee arthrodesis for the infected knee replacement. Clin Orthop Relat Res 2007;464:11-5.

28. Kutscha-Lissberg F, Hebler U, Esenwein SA, Muhr G, Wick M. Fusion of the septic knee with external hybrid fixator. Knee Surg Sports Traumatol Arthrosc 2006;14(10):968-74.

29. Spina M, Gualdrini G, Fosco M, Giunti A. Knee arthrodesis with the llizarov external fixator as treatment for septic failure of knee arthroplasty. J Orthop Traumatol 2010;11(2):81-8. Crossref

30. Wood JH, Conway JD. Advanced concepts in knee arthrodesis. World J Orthop 2015;6(2):202-10. Crossref

31. Balci HI, Saglam Y, Pehlivanoglu T, Sen C, Eralp L, Kocaoglu M. Knee Arthrodesis in Persistently Infected Total Knee Arthroplasty. J Knee Surg 2015. [Epub ahead of print]

32. Wu CH, Gray CF, Lee GC. Arthrodesis should be strongly considered after failed two-stage reimplantation TKA. Clin Orthop Relat Res 2014;472(11):3295-304. Crossref

33. Kostuik J, Alexander D. Arthrodesis for failed arthroplasty of the hip. Clin Orthop Relat Res 1984;(188):173-82.

34. Rao MC, Richards O, Meyer C, Jones RS. Knee stabilisation following infected knee arthroplasty with bone loss and extensor mechanism impairment using a modular cemented nail. Knee 2009;16(6):489-93. Crossref

35. Namdari S, Milby AH, Garino JP. Limb salvage after infected knee arthroplasty with bone loss and extensor mechanism deficiency using a modular segmental replacement system. J Arthroplasty 2011;26(6):977.e1-4. Crossref

36. Sierra RJ, Trousdale RT, Pagnano MW. Above-the-knee amputation after a total knee replacement: prevalence, etiology, and functional outcome. J Bone Joint Surg Am 2003;85-A(6):1000-4.

37. Chen AF, Kinback NC, Heyl AE, McClain EJ, Klatt BA. Better function for fusions versus above-the-knee amputations for recurrent periprosthetic knee infection. Clin Orthop Relat Res 2012;470(10):2737-45. Crossref 